\title{
Single Nucleotide Polymorphisms: An Approach to Personalized Medicine for African Americans with and without Type 2 Diabetes Mellitus
}

\author{
Lisa R Maness ${ }^{*}$, Jasmine L Barber, Jude Okoyeh \\ Winston-Salem State University, United States
}

Copyright $(2018$ by authors, all rights reserved. Authors agree that this article remains permanently open access under the terms of the Creative Commons Attribution License 4.0 International License

\begin{abstract}
Over 27 million people in the U.S. have type 2 diabetes mellitus, with a disproportionate number being African American. There is abundant evidence of environmental and genetic influence, with several single nucleotide polymorphisms reaching genome-wide significance. The work was a pilot study to begin to determine whether type 2 diabetes mellitus can be improved in society through personalized medicine, by approaching individual patients from the standpoint of their unique at-risk or protective genes in addition to lifestyle and family history. Twenty-seven patients volunteered to answer questions on family history of type 2 diabetes mellitus and had their body mass index, glucose, glycosylated hemoglobin, and insulin levels determined. They also had DNA extracted with single nucleotide polymorphisms determined by Affymetrix precision medicine research array. Fourteen single nucleotide polymorphisms relating to T2DM were found in the microarray used in this study. Number of at-risk single nucleotide polymorphisms varied for participants and 3 had the protective single nucleotide polymorphisms. While all participants had at-risk single nucleotide polymorphisms, some individuals with a body mass index in the obese range or with family history of the disease were found to have a greater number of single nucleotide polymorphisms that place them at risk for type 2 diabetes mellitus. This study shows how combined knowledge of patient single nucleotide polymorphisms, family history, and lab parameters may provide information for developing a personalized medicine plan.
\end{abstract}

Keywords African American Health, Type 2 Diabetes Mellitus, Personalized Medicine, Single Nucleotide Polymorphisms

\section{Introduction}

More than 30 million people in the U.S. suffer from diabetes, over $90 \%$ of which have type 2 diabetes mellitus (T2DM) [1]. Between 2013 and 2015, it was found that African Americans had a higher age-adjusted incidence at $12.7 \%$ compared to Caucasians with $7.4 \%$ of the population [(2]. There is also an enormous economic cost associated with T2DM, with total expenditure rising from \$174 billion to \$245 billion from 2007 to 2012[(3].

In 2015, President Barack Obama announced the Precision Medicine Initiative $\mathbb{R}$ in his State of the Union Address [4]. Precision medicine aims to reduce disease and tailor treatment by considering individual variations in lifestyle, genes, and environment. This initiative proposes to generate evidence-based practice needed to translate the notion of precision medicine into clinical practice, with the goal of focusing on individualized treatments. This is important since some current treatments are not successful for everyone suffering from a disease since individuals vary based on these factors.

In order to help the high number of African Americans who may have risk-factors for diabetes or who have already been diagnosed with the disease, precision medicine could potentially benefit in prevention of treatment. With that in mind, human genome studies have identified several single nucleotide polymorphisms (SNPs) that are significantly associated with patients with T2DM. For example, rs7560163 reached genome-wide significance in several studies [5,6]. Many other SNPs have been correlated with increases in T2DM specifically in African American individuals, such as rs2021785, rs6769511, and rs864745 [7-9]. Furthermore, several SNPs have been found to correlate with an increase of T2DM in AA individuals in more than one published study. For example, SNP rs7903146 was significantly correlated with T2DM in a genome wide association study (GWAS) by Long et al. and was found to correlate with an increased risk by McCormack et al. [5,8]. Alternatively, rs1421085 actually offers protection from T2DM for African American individuals with the $\mathrm{C}$ allele [10]). For prevention and treatments purposes, we now have the 
knowledge to move forward and use these findings to help individuals understand how their unique genetic variations may make them more predisposed to or protected from T2DM, or possibly a combination of each.

Patients may benefit from knowing the specific SNP alleles relating to T2DM that are represented in their genome. This knowledge can subsequently allow a personalized plan to be better developed even before their glucose, hemoglobin A1c ( $\mathrm{HbAlc})$, and insulin levels begin to falter. This could help prevent many cases of T2DM from occurring. In cases where patients are already considered as having "pre-diabetes", a plan can be better designed to prevent them from developing T2DM. In this study, African American participants were screened in order to determine family history of diabetes, to determine laboratory values that correlate with diagnosis of T2DM, and their DNA was extracted in order to determine which participants carry genes that are at-risk or protective toward the disease. This information was used to determine whether there is correlation between individual SNPs, family history, and lab values and to potentially begin to focus on personalized medicine plans for T2DM. To our knowledge, a study that includes presenting SNPs of individuals in comparison to lab values relevant to diabetes as well as their family history has not been presented before, especially in reference to conversations about personalized medicine.

\section{Materials and Methods}

African American patients visiting the Community Care Center in Winston-Salem, NC were asked to volunteer. After consent forms were signed, participants were briefly interviewed to determine whether or not they had ever been diagnosed with T2DM and whether they have a family history of diabetes. Participants without T2DM were assigned a number between $1 \mathrm{a}$ and 11 while those with T2DM were assigned a number between $2 \mathrm{a}$ and 21 , and those with "pre-diabetes" were assigned a number between $3 \mathrm{a}$ and $3 \mathrm{c}$. Age, sex, race, and body mass index (BMI) were also recorded. Non-fasting glucose levels were measured using TRUE METRIX PRO glucose meter by NIPRO Diagnostics [11]. HbA1c levels were measured using A1C NOW kit by PTS Diagnostics [12]. Insulin levels were determined using the Crystal Chem Insulin ELISA Kit [13]. DNA was extracted using Qiagen DNeasy Blood and Tissue Kit and then sent for Affymetrix Precision Medicine Research Array (PMRA) to AKESOgen [14-16]. The presence of SNPs relating to T2DM were determined for each participant.

\section{Results}

Each participant self-described himself/herself as
African American. Table 1 indicates results for each participant including age, sex, BMI, $\mathrm{HbAlc}$, and insulin as well as how the participant described any family history of diabetes. Study participants 1a-11 described themselves as not having T2DM, $2 \mathrm{a}-21$ as having T2DM, and $3 \mathrm{a}-3 \mathrm{c}$ as having pre-diabetes. Participants describing themselves as not having T2DM had an age range from 24 to 64 years, with 6 females and 6 males, BMI average of 33.0, glucose average of $98.1 \mathrm{mg} / \mathrm{dl}, \mathrm{HbA} 1 \mathrm{c}$ average of $5.8 \%$, and insulin level average of $9.2 \mathrm{mU} / 1$. Of 12 participants, 7 reported having any family history of diabetes. For those classified as having T2DM there were 6 females and 6 males, age range between 40 and 60 years, with averages as follows: BMI of 33.6, glucose of $127 \mathrm{mg} / \mathrm{dl}, \mathrm{HbAlc}$ of $6.8 \%$, and insulin level of $10.5 \mathrm{mU} / 1$. All except one reported some history of diabetes. Of the 3 self-reported patients with pre-diabetes, all were female ages 27,61 , and 64 , with one reporting a history of T2DM. Average values were as follows: glucose of $109 \mathrm{mg} / \mathrm{dl}, \mathrm{HbAlc}$ of $6.0 \%$, BMI of 38.7 , and insulin level of $17.3 \mathrm{mU} / 1$.

Table 2 indicates SNPs that were found in this study relating to T2DM along with the gene and/or specific alleles correlating with the disease as evidenced through previous genome studies. It also indicates whether this SNP has been previously shown to provide protection or increased risk of T2DM. Also included are the participants from this study that had the particular SNP allele, whether major or minor, and homozygous or heterozygous. Participants 1d, 1f, and 3a were found to be heterozygous for the protective $\mathrm{C}$ allele for rs 1421085 .

Table 3 indicates which major and minor alleles each participant had in their genome. Participant $1 \mathrm{~d}$ not only had the protective allele, but was also homozygous for the major allele for 7 at-risk SNPs and heterozygous for 4 others. Similarly, participant 1f was homozygous for major alleles for three at-risk SNPs, heterozygous for 7 others, and homozygous for one minor allele.

Of the SNPs that have been shown to increase the risk for T2DM in African Americans or all populations, all participants in the study were homozygous for several of these SNPs and almost all were heterozygous for more than one. All participants in the study were homozygous for the major allele of the SNP found to have genome-wide significance for risk of T2DM, rs7560163, except for 1e and $2 \mathrm{~h}$, both of whom were heterozygous for the SNP. Overall those participants who did not have diabetes were homozygous for 60 of the major alleles while those with the disease had 64. The group without diabetes were heterozygous for 41 major alleles while those with the disease had 32.

The Affymetrix Precision Medicine Research Array includes about 903,000 different SNPs [15]. Therefore, of the various SNPs previously shown to relate to T2DM, not all were found in this array and so what is represented in the data of this study are the SNPs that were among those included. For example, rs231362 was not found in this PMRA panel even though it was found in a study by Long 
et al. to be associated with a higher risk of T2DM when individuals carry the GA alleles for the KCNQ1 gene at this location [10]. None of the participants that volunteered for this study had the $A / G$ alleles of the rs 864745 or the
T/C alleles of the rs4689388 SNP. Alternatively, all participants were homozygous for the $\mathrm{C}$ allele for the rs1801282 SNP for the PPARG gene, except for participants $1 \mathrm{~g}$ and $1 \mathrm{i}$ who were heterozygous.

Table 1. Age, sex, BMI, glucose, $\mathrm{HbAlc}$, insulin, and any family history from all 27 African American patient volunteers

\begin{tabular}{|c|c|c|c|c|c|c|c|}
\hline Participant & Age & Sex & BMI & Glucose(mg/dl) & $\begin{array}{l}\mathrm{A1C} \\
(\%)\end{array}$ & $\begin{array}{l}\text { Insulin } \\
(\mathrm{mU} / \mathrm{l})\end{array}$ & $\begin{array}{l}\text { Family History (family member, if } \\
\text { offered) } *\end{array}$ \\
\hline 1a & 56 & M & 31 & 81 & 5.4 & 4.2 & Yes, Maternal Aunt \\
\hline $1 \mathrm{~b}$ & 24 & M & 22.2 & 117 & 5.4 & 3.9 & No \\
\hline $1 \mathrm{c}$ & 35 & $\mathrm{~F}$ & 66.8 & 90 & 5.7 & 4.8 & Yes \\
\hline $1 d$ & 43 & $\mathrm{~F}$ & 31.2 & 99 & 5.9 & 4.8 & No \\
\hline $1 \mathrm{e}$ & 46 & $\mathrm{~F}$ & 42.5 & 91 & 4.9 & 4.1 & No \\
\hline 1f & 37 & M & 28.6 & 106 & 7.3 & 3.1 & Yes \\
\hline $1 \mathrm{~g}$ & 44 & $\mathrm{~F}$ & 31.2 & 92 & 5.5 & 7.7 & No \\
\hline $1 \mathrm{~h}$ & 49 & $\mathrm{~F}$ & 31.8 & 117 & 6 & 3.5 & Mother; Grandfather (Type 1) \\
\hline $1 \mathrm{i}$ & 61 & M & 34.7 & 109 & 6.5 & 8.1 & Yes, 3 Brothers, 2 Sisters \\
\hline $1 \mathrm{j}$ & 64 & M & 27.4 & 95 & 5.8 & 6.9 & No \\
\hline $1 \mathrm{k}$ & 53 & M & 24.8 & 89 & 6.1 & 6.1 & Yes, Mother \\
\hline 11 & 26 & $\mathrm{~F}$ & 23.3 & 91 & 4.9 & 9.12 & Yes, Father \\
\hline $2 \mathrm{a}$ & 55 & M & 42 & 105 & 6.3 & 27.5 & Yes, Mother \\
\hline $2 b$ & 55 & M & 29.3 & 176 & 8.1 & 6.93 & Yes, Parents, 3 Brothers, 1 Sister \\
\hline $2 \mathrm{c}$ & 57 & M & 34.2 & 137 & 6.1 & 3.5 & Yes \\
\hline $2 d$ & 59 & M & 25.8 & 101 & 6.3 & 3.5 & Yes, Grandparents \\
\hline $2 \mathrm{e}$ & 61 & $\mathrm{~F}$ & 38.2 & 102 & 6.8 & 4.1 & Yes, Mother \\
\hline $2 f$ & 58 & M & 33.8 & 189 & 8.8 & 15.8 & Yes, Mother, Maternal Grandfather \\
\hline $2 \mathrm{~g}$ & 61 & M & 40.1 & 165 & 7.1 & 29.9 & Yes, Thinks Brothers Have Diabetes \\
\hline $2 \mathrm{~h}$ & 60 & $\mathrm{~F}$ & 30.1 & 98 & 5.8 & 4.6 & Yes \\
\hline $2 \mathrm{i}$ & 54 & $\mathrm{~F}$ & 31.7 & 91 & 6.2 & 5.0 & Yes \\
\hline $2 \mathrm{j}$ & 58 & $\mathrm{~F}$ & 28.5 & 81 & 6 & 6.9 & No \\
\hline $2 \mathrm{k}$ & 40 & $\mathrm{~F}$ & 38.8 & 97 & 5.6 & 13.8 & Yes, Grandmother \\
\hline 21 & 59 & $\mathrm{~F}$ & 30.6 & 182 & 8.2 & 4.9 & Yes, Mom and Grandmother \\
\hline $3 a$ & 27 & $\mathrm{~F}$ & 54.3 & 106 & 5.4 & 41.5 & Yes, Grandmother \\
\hline $3 b$ & 61 & $\mathrm{~F}$ & 38 & 103 & 6.7 & 4.6 & No \\
\hline $3 \mathrm{c}$ & 64 & $\mathrm{~F}$ & 23.8 & 118 & 5.8 & 5.8 & No \\
\hline
\end{tabular}

*yes responses are type 2 unless otherwise indicated participants in group $1=$ no diabetes, $2=$ diabetes, $3=$ prediabetes 
Single Nucleotide Polymorphisms: An Approach to Personalized Medicine for African Americans with and without Type 2 Diabetes Mellitus

Table 2. Participants with protective or at-risk allele for SNPs relating to diabetes.

\begin{tabular}{|c|c|c|c|c|c|}
\hline SNP & Gene/Allele(s)* & Impact on Diabetes & $\begin{array}{c}\text { HM Participants, Major } \\
\text { Allele }\end{array}$ & HT Participants & $\begin{array}{l}\text { HM Participants, } \\
\text { Minor Allele }\end{array}$ \\
\hline rs1421085 & FTO: C & Protective $\mathrm{e}^{5,10}$ & none & $1 \mathrm{~d}, 1 \mathrm{f}, 3 \mathrm{a}$ & N/A \\
\hline rs864745 & JAZF1: A/G & $\mathrm{AA}$ and $\mathrm{T} 2 \mathrm{DM}$ risk $^{9}$ & None & None & None \\
\hline rs2021785 & PCSK2: C/T & AA and $\mathrm{T} 2 \mathrm{D}$ risk $^{9}$ & $\begin{array}{c}1 \mathrm{~d}, 1 \mathrm{e}, 1 \mathrm{~g}, 1 \mathrm{~h} \\
2 \mathrm{a}, 2 \mathrm{~b}, 2 \mathrm{c}, 2 \mathrm{f}, 2 \mathrm{~h} \\
2 \mathrm{i}, 2 \mathrm{l}, 3 \mathrm{~b}, 3 \mathrm{c}\end{array}$ & $\begin{array}{l}1 \mathrm{a}, 1 \mathrm{~b}, 1 \mathrm{e}, 1 \mathrm{i}, 1 \mathrm{j}, 1 \mathrm{k}, 2 \mathrm{~d} \\
\quad, 2 \mathrm{e}, 2 \mathrm{~g}, 2 \mathrm{j}, 2 \mathrm{k}, 3 \mathrm{a}\end{array}$ & $1 \mathrm{c}$ \\
\hline rs6769511 & IGF2BP2: C/T & $\mathrm{AA}$ and $\mathrm{T} 2 \mathrm{DM}$ risk $^{8}$ & $\begin{array}{c}\text { 1a,1b,1c,1d,1e,1g, 1h, 1k, 2c, 2g, } \\
2 \mathrm{f}, 2 \mathrm{j}, 2 \mathrm{k}, 2 \mathrm{l}, 3 \mathrm{a}, 3 \mathrm{c}\end{array}$ & $1 \mathrm{f}, 1 \mathrm{j}, 2 \mathrm{~b}, 2 \mathrm{~d}, 2 \mathrm{e}, 3 \mathrm{~b}, 1 \mathrm{j}$ & None \\
\hline rs4689388 & $\begin{array}{c}\text { WFS1/PPP2R2C } \\
: \mathrm{T} / \mathrm{C}\end{array}$ & $\mathrm{AA}$ and $\mathrm{T} 2 \mathrm{DM}$ risk $^{8}$ & None & None & None \\
\hline rs 231362 & KCNQ1: G/A & $\mathrm{AA}$ and $\mathrm{T} 2 \mathrm{DM}$ risk $^{8}$ & SNP not in PMRA panel & & \\
\hline rs2237892 & KCNQ1: C/T & $\mathrm{AA}$ and $\mathrm{T} 2 \mathrm{DM}$ risk $^{8}$ & $\begin{array}{c}\text { 1a,1b,1c,1d,1g, 1i, 1k,11,2b,2c, } \\
2 \mathrm{~d}, 2 \mathrm{e}, 2 \mathrm{~g}, 3 \mathrm{~b}\end{array}$ & $\begin{array}{c}\text { 1e,1f,1h, } 1 \mathrm{j}, 2 \mathrm{a}, 2 \mathrm{f}, 2 \mathrm{k}, \\
3 \mathrm{a}\end{array}$ & $2 \mathrm{~h}, 3 \mathrm{c}$ \\
\hline rs 2237897 & KCNQ1: C/T & $\mathrm{AA}$ and $\mathrm{T} 2 \mathrm{DM}$ risk $^{8}$ & $\begin{array}{c}1 \mathrm{c}, 1 \mathrm{~d}, 1 \mathrm{f}, 1 \mathrm{~g}, 1 \mathrm{~h}, 1 \mathrm{k}, 2 \mathrm{a}, 2 \mathrm{~b}, 2 \mathrm{c}, 2 \mathrm{~d} \\
2 \mathrm{e}, 2 \mathrm{~h}, 2 \mathrm{i}, 2 \mathrm{j}, 2 \mathrm{l}, 3 \mathrm{a}, 3 \mathrm{~b}\end{array}$ & $\begin{array}{c}\text { 1a, } 1 b, 1 \mathrm{e}, 1 \mathrm{f}, 1 \mathrm{j}, 11,2 \mathrm{f} \\
2 \mathrm{~g}, 3 \mathrm{c}\end{array}$ & $2 \mathrm{~h}$ \\
\hline rs7903146 & $\begin{array}{l}\text { 1-TCF7L2: T/C } \\
\text { 2-T if low HDL, } \\
\text { obesity }\end{array}$ & $\begin{array}{c}\text { 1-AA and T2DM risk } \\
\text { 2-GWAS significance } \\
\text { correlating AA and } \\
\text { T2DM risk }\end{array}$ & $1 \mathrm{~b}, 2 \mathrm{~d}, 2 \mathrm{k}$ & $\begin{array}{c}1 \mathrm{a}, 1 \mathrm{~d}, 1 \mathrm{~g}, 11,2 \mathrm{~b}, 2 \mathrm{~g}, 2 \mathrm{i} \\
, 2 \mathrm{j}, 3 \mathrm{a}\end{array}$ & $\begin{array}{l}1 \mathrm{c}, 1 \mathrm{e}, 1 \mathrm{f}, 1 \mathrm{i}, 1 \mathrm{k}, 2 \mathrm{a}, 2 \mathrm{c}, \\
2 \mathrm{e}, 2 \mathrm{f}, 2 \mathrm{~h}, 2 \mathrm{k}, 3 \mathrm{~b}, 3 \mathrm{c}\end{array}$ \\
\hline rs 1801282 & PPARG: C & $\begin{array}{l}\text { AA in Europe and } \\
\text { T2DM risk }\end{array}$ & All participants except 1g,1i & $\mathrm{CG}=1 \mathrm{~g}, 1 \mathrm{i}$ & $\mathrm{N} / \mathrm{A}$ \\
\hline rs4402960 & IGF2PBP2:T & $\begin{array}{c}\text { All racial groups in } \\
\text { Europe }^{18}\end{array}$ & $1 \mathrm{c}, 1 \mathrm{e}, 1 \mathrm{~g}, 1 \mathrm{k}, 11,2 \mathrm{c}, 2 \mathrm{j}, 2 \mathrm{k}, 21,3 \mathrm{c}$ & $\begin{array}{l}\text { TG=1a, 1d,1f,1h,2b, } \\
2 \mathrm{e}, 2 \mathrm{f}, 2 \mathrm{~g}, 2 \mathrm{~h}, 2 \mathrm{i}, 3 \mathrm{a}, 3 \mathrm{~b}\end{array}$ & $\mathrm{~N} / \mathrm{A}$ \\
\hline rs 7560163 & $\mathrm{C} / \mathrm{G}$ & $\begin{array}{l}\text { GWAS significance } \\
\text { correlating AA and } \\
\text { T2DM risk } \\
\end{array}$ & All except $1 \mathrm{e}, 2 \mathrm{~h}$ & $1 \mathrm{e}, 2 \mathrm{~h}$ & None \\
\hline rs 7542900 & $\mathrm{C} / \mathrm{T}$ & AA and T2DM risk ${ }^{6}$ & $1 \mathrm{~d}, 1 \mathrm{j}, 11,2 \mathrm{~b}, 2 \mathrm{f}, 2 \mathrm{~g}, 2 \mathrm{~h}, 3 \mathrm{a}$ & $\begin{array}{c}\text { 1c,1e,1f,1g,1h,1i,2c } \\
, 2 \mathrm{~d}, 2 \mathrm{~g}, 2 \mathrm{i}, 2 \mathrm{k}, 3 \mathrm{~b}, 3 \mathrm{c}\end{array}$ & $1 \mathrm{a}, 1 \mathrm{~b}, 2 \mathrm{a}, 2 \mathrm{e}, 2 \mathrm{j}, 2 \mathrm{l}$ \\
\hline rs 7107217 & $\mathrm{C} / \mathrm{A}$ & $\mathrm{AA}$ and $\mathrm{T} 2 \mathrm{DM}$ risk $^{6}$ & $1 \mathrm{c}, 1 \mathrm{~g}, 2 \mathrm{a}, 2 \mathrm{e}, 2 \mathrm{k}, 3 \mathrm{a}, 3 \mathrm{~b}, 3 \mathrm{c}$ & $\begin{array}{c}\text { 1a,1d,1f,1h, } 1 \mathrm{i}, 1 \mathrm{j}, 1 \mathrm{k}, \\
11,2 \mathrm{~b}, 2 \mathrm{f}, 2 \mathrm{i}, 2 \mathrm{j}, 2 \mathrm{l}\end{array}$ & $1 \mathrm{~b}, 1 \mathrm{e}, 2 \mathrm{c}, 2 \mathrm{~d}, 2 \mathrm{~g}, 2 \mathrm{~h}$ \\
\hline
\end{tabular}

$\mathrm{AA}=$ African Americans, HM=homozygous, $\mathrm{HT}=$ heterozygous, *major/minor alleles; participants in group $1=$ no diabetes, $2=$ diabetes, $3=$ prediabetes

Table 3. SNPs with major and minor alleles for each participant.

\begin{tabular}{|c|c|c|c|}
\hline No Diabetes & SNPs & Diabetes & SNPs \\
\hline $1 \mathrm{a}$ & $\begin{array}{c}\text { Major,HM:rs6769511,rs2237892, rs1801282,rs7560163, } \\
\text { HT:rs2021785,rs2237897,rs7903146, } \\
\text { rs4402960,rs7107217 } \\
\text { Minor: rs7542900 }\end{array}$ & $2 a$ & $\begin{array}{c}\text { Major,HM:rs2021785, } \\
\text { rs2237897,rs1801282,rs7560163, rs7107217 } \\
\text { HT: rs2237892, } \\
\text { Minor:rs7542900 }\end{array}$ \\
\hline $1 \mathrm{~b}$ & $\begin{array}{c}\text { Major,HM:rs6769511,rs2237892, rs7903146, } \\
\text { rs1801282,rs7560163 } \\
\text { HT:rs2021785, rs2237897 } \\
\text { Minor:rs7542900, rs7107217 }\end{array}$ & $2 \mathrm{~b}$ & $\begin{array}{c}\text { Major,HM:rs2021785,rs2237892, rs2237897, } \\
\text { rs1801282,rs7560163,rs7542900 } \\
\text { HT: rs6768511, rs7903146,rs4402960, } \\
\text { rs7107217 } \\
\text { Minor:None }\end{array}$ \\
\hline $1 \mathrm{c}$ & $\begin{array}{c}\text { Major,HM:rs6769511, rs2237892, rs2237897, } \\
\text { rs1801282,rs7560163,rs4402960,rs7107217 } \\
\text { HT: rs7542900 } \\
\text { Minor:rs2021785, rs7903146 }\end{array}$ & $2 \mathrm{c}$ & $\begin{array}{c}\text { Major,HM:rs2021785,rs6769511, } \\
\text { rs2237892,rs2237897,rs1801282, } \\
\text { rs7560163,rs4402960 } \\
\text { HT:rs7542900 } \\
\text { Minor: rs7107217 }\end{array}$ \\
\hline 1d & $\begin{array}{c}\text { Major,HM:rs2021785, rs6769511, } \\
\text { rs2237892,rs2237897,rs1801282,rs7560163,rs7542900 } \\
\text { HT:rs1421085,rs7903146,rs4402960, rs7107217 } \\
\text { Minor:None } \\
\end{array}$ & 2d & $\begin{array}{c}\text { Major,HM: rs2237892,rs2237897, } \\
\text { rs7903146, rs } 1801282, r s 7560163 \\
\text { HT:rs2021785, rs6768511,rs7542900 } \\
\text { Minor: rs7107217 } \\
\end{array}$ \\
\hline $1 e$ & $\begin{array}{c}\text { Major, HM:rs6769511, rs2237897, rs1801282,rs4402960 } \\
\text { HT:rs2021785, rs2237892,rs7560163 } \\
\text { Minor: rs7903146, rs7107217 }\end{array}$ & $2 e$ & $\begin{array}{c}\text { Major,HM: rs2237892,rs2237897, } \\
\text { rs1801282,rs7560163, rs7107217 } \\
\text { HT:rs2021785,rs6768511, rs4402960 } \\
\text { Minor:rs7542900 }\end{array}$ \\
\hline 1f & $\begin{array}{l}\text { Major:HM:rs2237897,rs1801282,rs7560163 } \\
\text { HT:rs1421085, rs6768511, rs6768511, } \\
\text { rs2237892,rs4402960,rs7542900, rs7107217 } \\
\text { Minor: rs7903146 }\end{array}$ & $2 f$ & $\begin{array}{c}\text { Major,HM:rs2021785,rs6769511, rs2237897, } \\
\text { rs1801282,rs7542900 } \\
\text { HT: rs2237892,rs4402960, rs7107217 } \\
\text { Minor:None }\end{array}$ \\
\hline
\end{tabular}




\begin{tabular}{|c|c|c|c|}
\hline $1 g$ & $\begin{array}{c}\text { Major,HM:rs2021785, rs6769511, rs2237892, } \\
\text { rs2237897,rs7560163,rs4402960,rs7107217 } \\
\text { HT: rs7903146, rs1801282,rs7542900 } \\
\text { Minor:None }\end{array}$ & $2 \mathrm{~g}$ & $\begin{array}{c}\text { Major,HM: rs6769511,rs2237892, } \\
\text { rs2237897, rs1801282,rs7560163,rs7542900 } \\
\text { HT:rs2021785, rs7903146, rs4402960, } \\
\text { rs7542900 } \\
\text { Minor: rs7107217 }\end{array}$ \\
\hline $1 \mathrm{~h}$ & $\begin{array}{c}\text { Major,HM:rs2021785, rs6769511, } \\
\text { rs2237897,rs1801282,rs7560163 } \\
\text { HT: rs2237892,rs4402960,rs7542900, rs7107217 } \\
\text { Minor:None }\end{array}$ & $2 \mathrm{~h}$ & $\begin{array}{c}\text { Major,HM:rs2021785,rs2237897,rs } 1801282, \\
\text { rs7542900 } \\
\text { HT: rs7560163,rs4402960 } \\
\text { Minor: rs2237892,rs2237897, rs7107217 }\end{array}$ \\
\hline $1 \mathbf{i}$ & $\begin{array}{c}\text { Major,HM: rs2237892,rs7560163 } \\
\text { HT:rs2021785,rs1801282,rs7542900, rs7107217 } \\
\text { Minor: rs7903146 }\end{array}$ & $2 \mathbf{i}$ & $\begin{array}{c}\text { Major,HM:rs2021785,rs2237897, } \\
\text { rs1801282,rs7560163 } \\
\text { HT: rs7903146,rs4402960,rs7542900, } \\
\text { rs7107217 } \\
\text { Minor:None }\end{array}$ \\
\hline $1 \mathbf{j}$ & $\begin{array}{c}\text { Major,HM: rs2237897,rs1801282,rs7560163, rs7542900 } \\
\text { HT:rs2021785, rs6768511, rs2237892, rs7107217 } \\
\text { Minor:None }\end{array}$ & $2 \mathrm{j}$ & $\begin{array}{c}\text { Major,HM: rs6769511 rs2237897, } \\
\text { rs1801282,rs7560163,rs4402960 } \\
\text { HT:rs2021785, rs7903146, rs7107217 } \\
\text { Minor:rs7542900 }\end{array}$ \\
\hline $1 \mathrm{k}$ & $\begin{array}{c}\text { Major,HM: rs6769511, rs2237892, rs2237897, } \\
\text { rs1801282,rs7560163,rs4402960 } \\
\text { HT:rs2021785, rs7107217 } \\
\text { Minor: rs7903146 }\end{array}$ & $2 k$ & $\begin{array}{c}\text { Major,HM: rs6769511,rs7903146, } \\
\text { rs1801282,rs7560163,rs4402960, rs7107217 } \\
\text { HT:rs2021785, rs2237892, rs7542900 } \\
\text { Minor:None }\end{array}$ \\
\hline \multirow[t]{5}{*}{11} & $\begin{array}{c}\text { Major,HM: rs2237892, rs2237897, } \\
\text { rs1801282,rs7560163,rs4402960,rs7542900 } \\
\text { HT: rs7903146, rs7107217 } \\
\text { Minor: rs7903146 }\end{array}$ & 21 & $\begin{array}{c}\text { Major,HM:rs2021785,rs6769511, rs2237897, } \\
\text { rs1801282,rs7560163, rs4402960 } \\
\text { HT: rs7107217 } \\
\text { Minor:rs7542900 }\end{array}$ \\
\hline & & Pre-Diabetes & \\
\hline & & $3 a$ & $\begin{array}{c}\text { Major,HM: rs6769511,rs7542900,rs2237897, } \\
\text { rs1801282,rs7560163,rs7107217,rs7542900, } \\
\text { rs7107217 } \\
\text { HT:rs2021785, rs2237892 } \\
\text { rs7903146,rs4402960,rs1421085 } \\
\text { Minor:None }\end{array}$ \\
\hline & & $3 \mathbf{b}$ & $\begin{array}{c}\text { Major,HM:rs2021785,rs2237892, rs2237897, } \\
\text { rs1801282,rs7560163, rs7107217 } \\
\text { HT: rs6768511,rs4402960,rs7542900 } \\
\text { Minor: }\end{array}$ \\
\hline & & $3 c$ & $\begin{array}{c}\text { Major,HM:rs2021785,rs6769511, } \\
\text { rs2237897,rs1801282,rs7560163, rs4402960, } \\
\text { rs7107217 } \\
\text { HT: rs7542900 } \\
\text { Minor: rs2237892 }\end{array}$ \\
\hline
\end{tabular}

$\mathrm{HM}=$ homozygous, $\mathrm{HT}=$ heterozygous, major/minor alleles; participants in group 1=no diabetes, $2=$ diabetes, $3=$ prediabetes

\section{Discussion}

What can be inferred from the information in the tables includes potential benefits of precision medicine for each study participant. The participants with the protective $\mathrm{C}$ allele of rs1421085 indeed reported as either not having diabetes or having pre-diabetes; however, the HbA1c of $1 \mathrm{~d}$ was 5.9 and that of $1 \mathrm{f}$ was 7.3. This suggests that these patients may benefit some personalized care from the healthcare provider to prevent T2DM. In addition, participant $3 \mathrm{a}$ who self-reported as having pre-diabetes has a BMI of 54.3, HbA1c of 5.4, and a grandmother with T2DM. She had the greatest number of at-risk SNPs found in this study at twelve, along with the one SNP associated with protection against the disease. A physician might share this information with her and recommend decreasing her BMI along with a healthier diet in order to decrease the risk of her further developing T2DM. The provider could help develop a personalized plan to reach these goals as a vital component of health-related counselling after speaking with her about her genetic and family-history risk factors. Thus, this personalized counselling model can be extended to each participant in this study with the aim of optimizing the patient's treatment outcome.

In another example, individual 1a is a 56-year-old male without diabetes, but with an elevated BMI and a maternal aunt with T2DM despite having normal glucose and HbA1c values. Individual 1a does have a number of at-risk alleles for T2DM, including being homozygous for major at-risk alleles for rs6769511, rs2237892, rs1801282, rs7560163 and heterozygous for rs2021785, rs2237897, rs7903146, rs4402960, and rs7107217. In addition, according to Yan et al. if an obese patient has low HDL with the T allele at rs7903146, the patient is at increased risk for T2DM [17]. Participant 1a is indeed obese according to his BMI of 31, but we do not have the HDL value. Making this individual aware of this information may allow him to realize the importance of working to 
decrease the BMI through healthier eating and increased exercise since these SNPs make him more at-risk for T2DM. Practitioners can also determine a personalized plan for this participant and set healthier goals accordingly. Similarly, patient $1 \mathrm{f}$ has the greatest number of at-risk SNPs of all the participants without diabetes in the study, suggesting that a personalized plan to prevent the onset of T2DM could be beneficial, perhaps by focusing on reducing the $\mathrm{HbA} 1 \mathrm{c}$ and reducing the BMI. The reported HbAlc of 7.3 for participant $1 \mathrm{f}$ is great enough to be considered having diabetes and it could be that this was a new, as of yet, undiscovered case.

The participant in this study with diabetes having the most at-risk SNP alleles was $2 \mathrm{~g}$ with eleven. For six of these she was homozygous for the major allele, heterozygous for 4 of the major alleles, and she had one minor allele. This participant had a BMI of 40.1, HbA1c of 7.1, and believes she has brothers with the disease. If a practitioner shared the information of her risk factors for T2DM, this may allow her to better understand that she will need to stick with a developed plan to reduce the BMI and $\mathrm{HbAlc}$ values. It would be more advantageous to identify these risk factors well before the patient's HbAlc increases and develops symptoms of T2DM. Perhaps many more patients can prevent the onset by knowing their genetic risk factors early in life.

\section{Conclusions}

To our knowledge, studies comparing patient SNPs with lab values and family history has not been done before. This study indicates how knowledge of individual parameters such as BMI, glucose, HbAlc, and family history as well as specific protective and high-risk SNPs may be important in the development of a plan for personalized medicine from practitioners. Patients who have family history of T2DM or who have prediabetes can use this collective information to improve their health status through necessary nutritional adjustments and increased physical exercise under the care of a practitioner. Patients who have already been diagnosed with T2DM, if made aware of the complex relationship between their unique family history, present blood values and BMI, and specific genes that make them more at-risk can better understand their personal relationship with the disease in order to better control it. Since African Americans have a greater number of cases of diabetes than Caucasians, increasing the use of personalized medicine for treatment of this disease could be of great benefit, personally and on an economic level.

\section{Acknowledgements}

We would like to thank the Community Care Center of Winston-Salem, NC, the Research Initiative Program of
Winston-Salem State University, and the Clinical Laboratory Science and Nursing Departments of Winston-Salem State University.

\section{Disclosures}

\section{None}

Abbreviations: type 2 diabetes mellitus (T2DM), single nucleotide polymorphism (SNP), body mass index (BMI), African Americans (AA)

Human Genes: JAZF1 $=$ juxtaposed with another zinc finger gene $1, \quad$ PCSK $2=$ proprotein convertase subtilisin/kexin type2, IGF2BP2= insulin like growth factor 2 mRNA binding protein 2, WFS1 = wolframin ER transmembrane glycoprotein, $\mathrm{PPP} 2 \mathrm{R} 2 \mathrm{C}=$ protein phosphatase 2 regulatory subunit Bgamma, KCNQ1= potassium voltage-gated channel subfamily $\mathrm{Q}$ member 1 , TCF7L2 $=$ transcription factor 7 like 2, PPARG= peroxisome proliferator activated receptor gamma.

\section{REFERENCES}

[1] Center for Disease Control and Prevention. Type 2 diabetes. 2018. Online available https://www.cdc.gov/diabetes/basic s/type $2 . h t m l$.

[2] American Diabetes Association. Statistics about diabetes. 2018. Online available http://www.diabetes.org/diabetes-b asics/statistics/.

[3] American Diabetes Association. The Cost of diabetes. 2018. Online available http://www.diabetes.org/advocacy/news-ev ents/cost-of-diabetes.html.

[4] The Precision Medicine Initiative. The White House, President Barack Obama. 2016. Online available https://obamawhitehouse.archives.gov/node/333101.

[5] S. McCormack, S. Grant. Genetics of obesity and type 2 diabetes in African Americans. Journal of Obesity, No. 396416, 2013.

[6] N. Palmer, C. McDonough, P. Hicks, B. Roh, M. Wing, S. An, et al. A genome-wide association search for type 2 diabetes genes in African Americans. PLoS One, Vol. 7, No. e29202, 2012.

[7] T. Leak, K. Keene, C. Langefeld, C. Gallagher, J. Mychaleckyj, B. Freedman, et al. Association of the proprotein convertase subtilisin/kexin-type 2 (PCSK2) gene with type 2 diabetes in an African American population. Molecular Genetics and Metabolism, Vol. 176, 145-50, 2007.

[8] J. Long, T. Edwards, T. Signorello, Q. Cai, W. Zheng, X. Shu, et al. Evaluation of genome-wide association study-identified type 2 diabetes loci in African Americans. American Journal of Epidemiology, No. 176:995-1001, 2012.

[9] K. Langberg, L. Ma, N. Sharma, C. Hanis, S. Elbein, S. 
Hasstedt, et al. Single nucleotide polymorphisms in JAZF1 and BCL11A gene are nominally associated with type 2 diabetes in African-American families from the GENNID study. Journal of Human Genetics, Vol. 57, 57-61, 2012.

[10] J. Bressler, W. Kao, J. Pankow, E. Boerwinkle. Risk of type 2 diabetes and obesity is differentially associated with variation in FTO in whites and African-Americans in the ARIC study. PLoS One, Vol. 5, No. e10521, 2010.

[11] Nipro Diagnostics. TRUE METRIX PRO. 2014. Online available http://www.trividiahealth.com/our products/dow nloads/bgm true metrix/TMX_PRO_ResourceGuide_US MKT0523r1.pdf.

[12] PTS Diagnostics. A1C Now ${ }^{\circledR}$ Systems. 2018. Online available http://www.ptsdiagnostics.com/a1 cnow-systemsoverview.html.

[13] Crystal Chem. Insulin ELISA Kit. 2018. Online available http://www.crystalchem.com/insulin-elisa-kit.html.

[14] Qiagen. DNeasy Blood and Tissue Kits. 2018. Online available https://www.qiagen.com/us/shop/sample-technolo gies/dna/genomic-dna/dneasy-blood-and-tissue-kit/\#orderi nginformation

[15] Thermofisher. Affymetrix Axiom Precision Medicine Research Array. 2017. Online available https://www.therm ofisher.com/order/catalog/product/902981.

[16] AKESOgen. Genomics by Design. 2018 http://www.akeso gen.com/.

[17] Y. Yan, K. North, C. Ballantyne, F. Brancati, L. Chambless, N. Franceschini, et al. Transcription factor 7-like 2 (TCF7L2) polymorphism and context-specific risk of type 2 diabetes in African American and Caucasian adults: the atherosclerosis risk in communities studies. American Diabetes Association. Vol., 58, No. 1, 285-289, 2009.

[18] K. Waters, D. Stram, M. Hassanein, L. Marchand, L. Wilkens, G. Maskarinec, et al. Consistent association of type 2 diabetes risk variants found in Europeans in diverse racial and ethnic groups. PLoS Genetics. Vol.6, No. 8, 2010. 